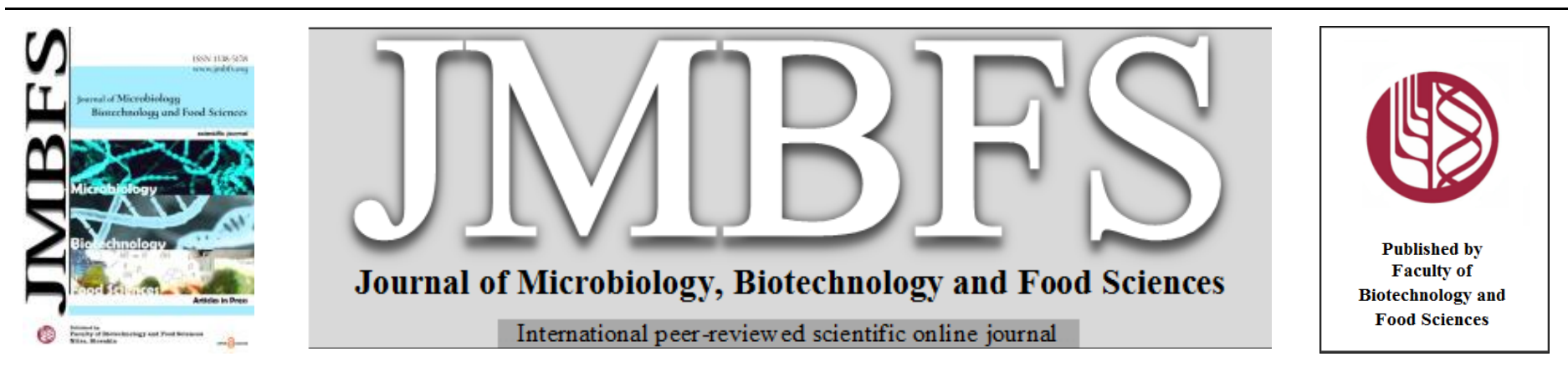

\title{
FOOD PATTERN LINK TO COVID19: THE ROLE OF DIET AND NUTRITIONAL SUPPLEMENT DURING A WORLD WIDE HEALTH CATASTROPHE
}

\author{
Sanchita Baisyal , Abinit Sahal , Joydeep Paul ${ }^{1}$, Rudra Sahal and Arpita Das ${ }^{1 *}$
}

Address(es):

${ }^{1}$ Department of Biotechnology, Adamas University, Barasat- Barrackpore road, 24 Parganas North, Jagannathpur, Kolkata, West Bengal 700126, India.

*Corresponding author: arpita.das@adamasuniversity.ac.in

https://doi.org/10.55251/jmbfs. 3503

\section{ARTICLE INFO}

Received 26. 7. 2020

Revised 27. 1. 2022

Accepted 31. 1.2022

Published 1. 6. 2022

\section{Regular article}

OPEN OACCESS

\begin{abstract}
Nutritional diet and essential bioactive supplements can shape out to be a vital technique to attain healthy and well-balanced body functioning. Unhealthy dietary habits can result into various physical ailment and one becomes prone to various disease because of the same. COVID-19 infection depends on a two-phase immune response and the risk of infection or overcoming the infection is higher for stronger immune system. In this piece of writing we have correlated the properties of certain immunity strengthening food against the risk of various viral infections. We had also conducted a survey with people living all across India to study the change in food pattern and preferences during this pandemic lockdown situation and have presented them in graphical format. A healthy diet consisting of various components like minerals, zinc, iron, vitamin $\mathrm{C}$, vitamin $\mathrm{D}$, vitamin $\mathrm{E}$ has been seen to improve immune system and strengthens it.
\end{abstract}

Keywords: COVID-19, immune-response, healthy diet, Functional food formulation, food-pattern, bioactive elements

\section{INTRODUCTION}

Due to rapid westernization and urbanization of the developing economies in the world many changes in lifestyle and food pattern have also been noticed. These changes are mostly shifted towards one of high fat, high energy-dense foods and a sedentary lifestyle (Popkin, 2001). Unhealthy food habits result into various negative physical impacts like obesity, cardiovascular diseases, diabetes. Unhealthy dietary habits categorised by the intake of fast foods, overeating of fatty and greasy food, drinking of sugar sweetened beverages, highly flavoured food, too pungent food, less amount of fruits and vegetables intakes contributes for various disease (Olumakayie et al. 2010). A healthy diet and lifestyle can not only reduce the chances of occurrence of many diseases, but also improve our immunity (Ali et al. 2019). Lung inflammation is one of the main reasons of severe ailments of the disease caused by COVID-19. The corona virus will proliferate and cause injury in cells, induce innate inflammation mediated by granulocytes and proinflammatory macrophages in the lungs which is the evidence of two-phase immune response brought by the COVID-19 specially (Shi et al. 2020).

COVID19: The disease, outlook on immune-response

Coronaviruses exist as a giant family of different infectious viruses. Some of them cause the common cold in people, others infect animals comprising bats, camels and cattle. Many patients were been admitted in Wuhan hospital back on December 2019 with Viral Pneumonia of Unknown Etiology (VPUE). Later it was found that many of them has formerly worked in a selling hub of animals named Huanan Seafood Wholesale Market. After various analysis (medical, chemical, structural) it was confirmed that this was due to novel $\beta$-genus coronavirus $(2019-\mathrm{nCoV})$ and also termed as novel coronavirus-infected pneumonia (NCIP) (Ali et al. 2019). In Jin Yin-tan hospital, Wuhan, from the diagnosis of patients, it was found that some common symptoms of SARS and MARS are fever, dyspnea, cough with a prolonged bilateral ground-glass appearance on chest CT scans. Complication includes acute respiratory distress syndrome (ARDS), cardiac injury etc. (Huang et al. 2020).

Puzzling similarities and noticeable amino acid homology are obtained between SARS-CoV and SARS-CoV2 is seen between them by genomic sequence analyses and oxygen therapy is clinically required in both illnesses (Paules et al. 2020).

Pathological characteristics was investigated in patient who had severe infection with SARS-CoV-2, and clinically proven that it reflects two-phase immune response (Xu et al. 2020). Immune defence-based shielding phase and inflammation-driven detrimental phase are two different phases engaged in this infection. Enhancing immune responses during shielding phase and suppressing detrimental phase are recommended (Shi et al. 2020). Healthy diet is the key to boost immunity which plays a key role to fight against any infection. Food pattern is the vital role payer in achieving total nutritional support from the food or food supplements.

An online survey with 130+ people from different parts of India for the better underrating of food awareness toward the mass.

Lockdown during Covid19 pandemic has opened the options for many people to revive the joy of cooking along with their family members which impacted in significant reduction of food waste. Adequate storage of food was one of the concerns during the initial days of locked down. Local markets were the primary source for raw food however packed/processed food were also in demand to store. An online survey was conducted with $130+$ people across the country for a view of the demand of food during this pandemic. Some of the significant questions were being asked for the survey.

- Which type of food you prefer during lockdown?

- Which type of processed food you have purchased from the market during lock down?

- If a healthy food is manufactured, what are the benefits you love to see in it?

Review analysis were made with the responses from different part of the country, different genders and ages working in different sectors. $97 \%$ of the respondents opted for home cooked food (Figure1) which clearly suggests awareness of social distancing and preference to restrict themselves from going out for restaurants and local fast-food outlets. 


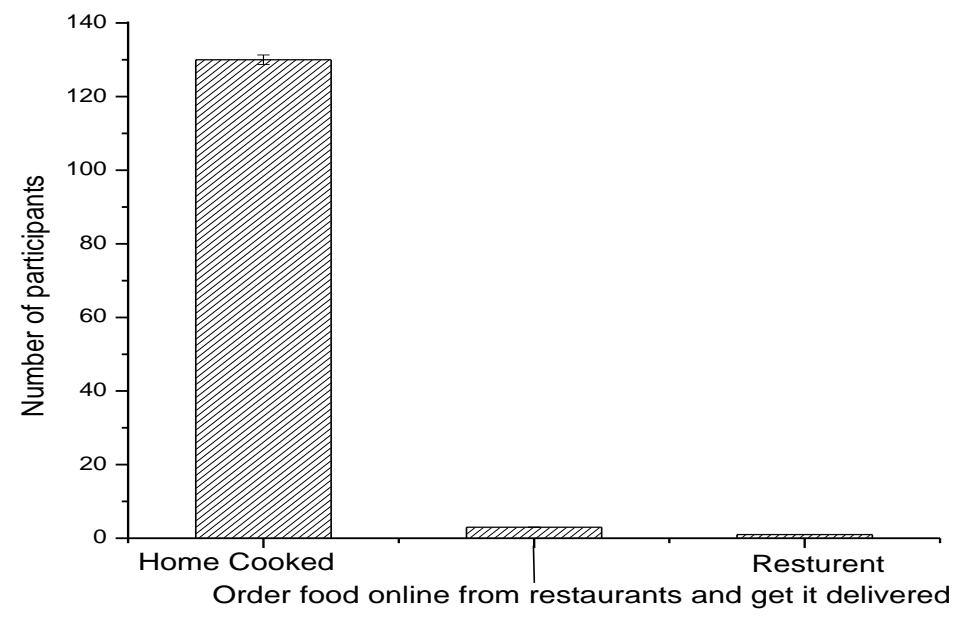

Figure 1 Food Preference during the lockdown Period

Panic button was on during the initial phases of the lockdown; people started stockpiling food for future adverse situations. During this time, $74 \%$ relied on the raw material for recipe making and around $16 \%$ people chosen to have ready to cook food (Figure 2).

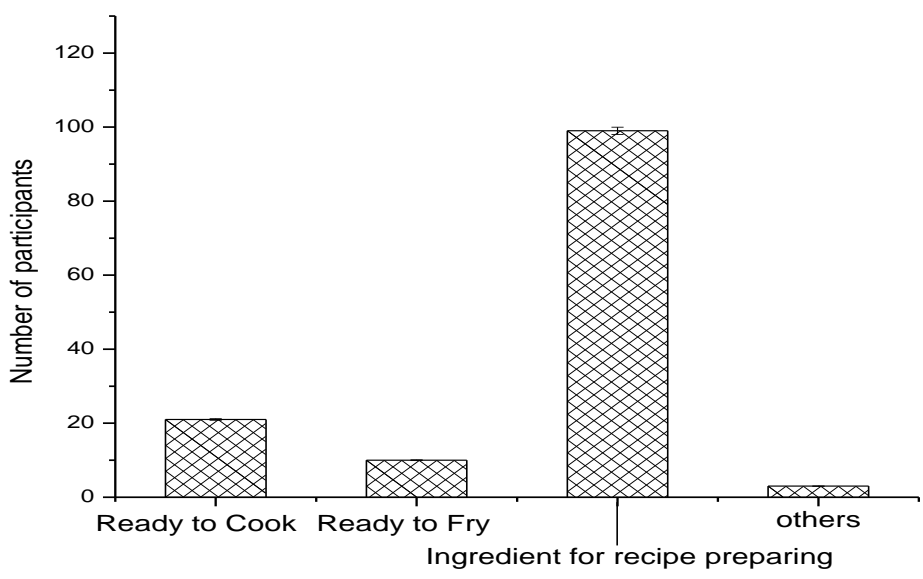

Figure 2 Type of processed food generally bought from market during lockdown

This is consequential that recipe making items are none other than perishable, semi perishable or non-perishable food but proper packaging and storing those in appropriate conditions for longer shelf-life is most important.

Finally, to answer the last question majority suggested it must be novel product with value addition; it must be low cost and should contain minimum thermal processing. Consumers want conversion of meals to functional meals.

\section{Required nutrients: their roles and food sources}

It's not garneted that any food or food supplement can defend us from getting infected by the virus (COVID-19). It is obvious that healthy diet will improve the immunity which in deed is the key to fight against infection, like all the nutrients of proteins, carbohydrates, fats, vitamins and minerals in an adjusted proportion with the implementation of healthy eating habits, generally emphasizing on fruits, vegetables, whole grains, legumes, nuts for their content of proteins and magnesium also moderate consumption of fish because they contain zinc which works to produce blood cells that fight infection, dairy products, poultry as they contain many useful nutrients, yogurt, mushrooms, garlic and olive oil, which contain antioxidants (Donsbach et al. 1985). Olive oil, soyabean oil, rice bran oil, canola should be added in dietary fat of daily diet instead of crash weight loss diet. While choosing the nutrition enriched diet of a patient, emphasis should be given on their age, genetic background, nutritional status, pre-existing health conditions etc (Dayong et al. 2019). Nutrition, infection and immunity has unique relations within them. Even if a meagre nutritional state spoils the immune system which in turn leads to infections, in some instances the immune response to an infection can itself damage or alter body composition and Nutitional desires (Scrimshaw et al. 1997).

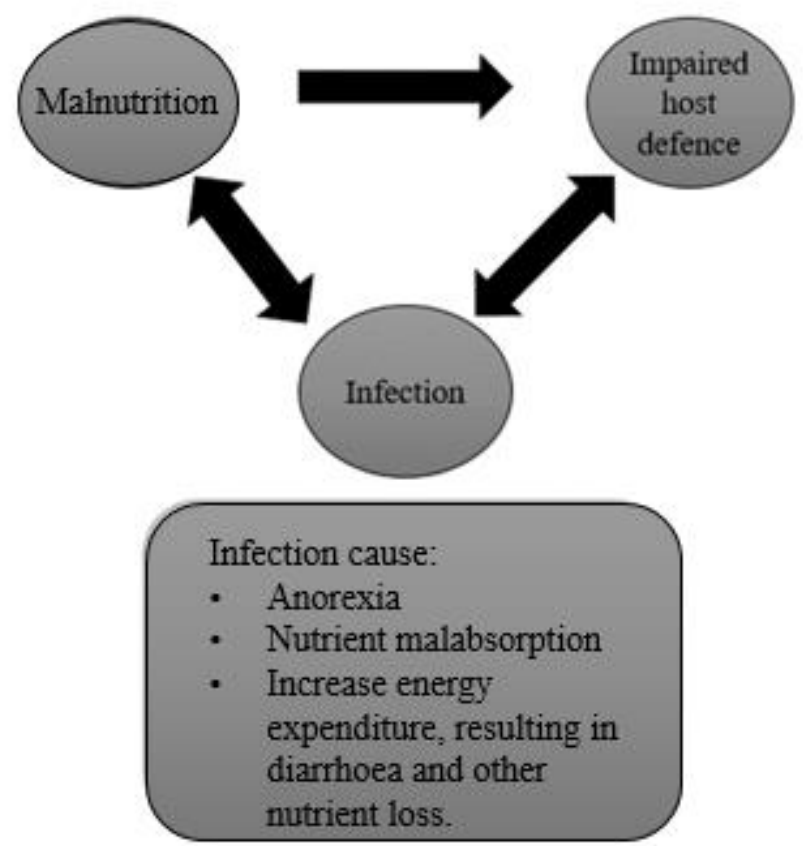

Figure 3 Interaction between infection, under Nutrition and impaired host defence

From figure 3 we can conclude that a nutrient intake should never coincide with the desired nutrient requirement during infection or else it can cause reduced nutrient absorption and nutrient losses. In table 1 certain bioactive compounds are studied with their role in immune system and the food source.

\section{Role of functional foods towards managing infection}

Functional food from our routine life has been seen to have impacted our livelihood and the effect of it towards managing various kind of infections. From Table 1 we studied different bioactive elements and its food sources. Also the table portrays methodically what are the role of those bioactive elements in the human immune system.

\section{Food-drug interaction}

Food and drugs both of them are key role player in this pandemic situation to maintain the health status of an individual (Lars et al. 2002). Lifestyle and diet may be able to cause significant impact on drugs. Food drug interaction is a condition in which efficacy of drug may get effected by the food, so these kinds of interactions are to be avoided, due to the possibility of poor or unexpected outcomes (Rabia et al. 2010). As both food and drug both absorbed through the lining of the stomach or the small intestine, taking them together should be avoided to reduce the risk.

\section{CONCLUSION}

Keeping in mind the current world-wide health catastrophe of COVID-19, we tried to set a link of the food pattern and Nutrition to it. It's predominant from the survey that people are aware of the consequences of the pandemic and they are also aware of the fact that immunity will play a key role to fight against COVID-19. Studying the immune response of SARS COV2, it can be clearly concluded that a sound immune system is the key for endurance and reduces the severity of COVID-19 infection. In due course we discussed the value of healthy diet to allow immune system to function properly. Prescribed amount of beneficial food which are good source of bioactive elements are the options to avoid crash diet. Target areas for next generation food are high nutritional value, multi functionality and long shelflife. Smart food having additional values are the point of interest for the consumers now. Amidst this pandemic situation, Food Biotechnologies can foresee a new ray of hope which can serve us in future pandemic-like situations. 
Table Bioactive compounds their role in immune system and food source

\begin{tabular}{|c|c|c|c|}
\hline Bioactive elements & Role in immune system & Food Source & Reference \\
\hline Minerals & $\begin{array}{l}\text { Sipping into small amounts of water, in the early } \\
\text { morning an empty stomach and half an hour before } \\
\text { meals, strengthens the metabolism rate. Even small cup } \\
\text { of water before bathing helps to lower the blood } \\
\text { pressure and a cup of water before sleep prevents heart } \\
\text { attack. Drinking water also works on the sedimentation } \\
\text { of mucous membranes lining the respiratory tract, which } \\
\text { helps the production of antibodies and white blood cells, } \\
\text { thereby strengthening the immune system's } \\
\text { performance. }\end{array}$ & Drinking water & $\begin{array}{c}\text { (Popkin et al. 2010), (Petraccia } \\
\text { et al. 2006) }\end{array}$ \\
\hline Vitamin C & $\begin{array}{l}\text { contributes to immune defence system by supporting } \\
\text { both the innate and adaptive immune system. }\end{array}$ & $\begin{array}{l}\text { Citrus fruits, papaya, } \\
\text { kiwi, green vegetables }\end{array}$ & (Dhandevi et al. 2015) \\
\hline $\begin{array}{l}\text { Rich in yeast and } \\
\text { increases the } \\
\text { amount of useful } \\
\text { bacteria. }\end{array}$ & $\begin{array}{l}\text { They play a vibrant role in fermenting plant fibres and } \\
\text { transforming them into chemicals which when enters the } \\
\text { bloodstream helps in strengthening the immunity } \\
\text { system. }\end{array}$ & $\begin{array}{l}\text { Dairy product such as } \\
\text { fermented milk and } \\
\text { skimmed yogurt, turkey } \\
\text { cheese. }\end{array}$ & (Conlon et al. 2015) \\
\hline Zinc & $\begin{array}{l}\text { Zinc is known for its antioxidant activity; it acts as } \\
\text { immune boosting agent too. Decreased level of serum } \\
\text { testosterone level, severe immune dysfunctions mainly } \\
\text { affecting T helper cells, oligospermia, } \\
\text { hyperammonemia, neurosensory disorders these are } \\
\text { some derogatory effects of } \mathrm{Zn} \text { deficiency. }\end{array}$ & $\begin{array}{l}\text { Chicken leg, tofu, } \\
\text { lentils, low-fat yoghurt, } \\
\text { oats }\end{array}$ & (Prasad et al. 2000) \\
\hline Iron & $\begin{array}{l}\text { Iron deficiency can cause atrophy in thymus and also } \\
\text { has multiple effects on immune function in human. }\end{array}$ & $\begin{array}{l}\text { Egg, broccoli, pumpkin } \\
\text { seeds, brown rice, } \\
\text { quinoa. }\end{array}$ & (Sherman et al. 1993) \\
\hline Vitamin D & $\begin{array}{l}\text { Deficiency in vitamin D is mainly associated with } \\
\text { increased susceptibility to infection as well as increased } \\
\text { autoimmunity. }\end{array}$ & $\begin{array}{l}\text { Spinach, soybean, egg } \\
\text { yolk, fatty fish like tuna, } \\
\text { orange juice. }\end{array}$ & (Sabetta et al. 2020) \\
\hline Vitamin E & $\begin{array}{l}\text { Vitamin } E \text { is a source of lipid-soluble antioxidant for the } \\
\text { body. It is also seen to escalate vulnerability of animals } \\
\text { to infectious pathogens. }\end{array}$ & $\begin{array}{l}\text { Hazelnuts, nuts, } \\
\text { almonds, peanuts, } \\
\text { cashew nuts, sunflower } \\
\text { seeds, spinach. } \\
\end{array}$ & (Meydani et al. 1998) \\
\hline
\end{tabular}

Declarations: Financially supported by Seed fund grant (Ref. No.AU/REG/201920/12/008), under Adamas University, India.

Conflict of interest: There is no conflict of interest.

\section{REFERENCE}

Ali, H. I., Al-Shawi, S. G., \& Habib, H. N. (2019). The Effect of Nutrition on Immune System Review Paper. Food Science and Quality Management, 90, 31 35. https://doi.org/10.7176/FSQM

Ali, S. A., Baloch, M., Ahmed, N., Ali, A. A., \& Iqbal, A. (2020). The outbreak of Coronavirus Disease 2019 (COVID-19)_An emerging global health threat. Journal of infection and public health, 13(4), 644-646. https://doi.org/10.1016/j.jiph.2020.02.033

Bushra, R., Aslam, N., \& Khan, A. Y. (2011). Food-drug interactions. Oman medical journal, 26(2), 77. https://doi.org/10.5001/omj.2011.21

Conlon, M. A., \& Bird, A. R. (2015). The impact of diet and lifestyle on gut microbiota and human health. Nutrients, 7(1), 17-44. https://doi.org/10.3390/nu7010017

Daisy Whitebread, June 27th, 2020 "Top 10 Foods Highest in Zinc" https://www.myfooddata.com/articles/high-zinc-foods.php

Dayong,Wu., Erin, D, L., Munyong, P., Simin, N, M. (2019). Nutritional Modulation of Immune Function: Analysis of Evidence, Mechanisms, and Clinical Relevance. Frontiers in immunology. 15(9), 3160.https://doi.org/10.3389/fimmu.2018.03160

Dhandevi, P. E. M., \& Jeewon, R. (2015). Fruit and vegetable intake: Benefits and progress of nutrition education interventions-narrative review article. Iranian

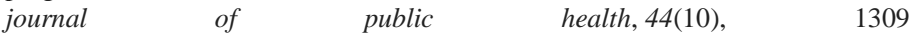
https://www.ncbi.nlm.nih.gov/pmc/articles/PMC4644575/

Donsbach, K. W. (1985). Donsbach's Guide to Good Health-Long. Shadow Book Huang, C., Wang, Y., Li, X., Ren, L., Zhao, J., Hu, Y., ... \& Cao, B. (2020). Clinica features of patients infected with 2019 novel coronavirus in Wuhan, China. The lancet, 395(10223), 497-506. https://doi.org/10.1016/S0140-6736(20)30183-5

Meydani, S. N., \& Beharka, A. A. (1998). Recent developments in vitamin E and immune response. Nutrition Reviews, 56(1), S49. https://doi.org/10.1111/j.17534887.1998.tb01644.x

Olumakaiye, M. F., Ogbimi, G. F., Ogunba, B. O., \& Soyebo, K. O. (2010) Snacking as a Contributor to Overweight among Nigerian Undergraduate
Students. Nigerian Journal of Nutritional Sciences, 31(2), 76-80 https://www.ajol.info//index.php/njns/article/view/63921

Pae, M., Meydani, S. N., \& Wu, D. (2012). The role of nutrition in enhancing immunity in aging. Aging and disease, 3(1), 91 https://www.ncbi.nlm.nih.gov/pmc/articles/PMC3320807/

Paules, C. I., Marston, H. D., \& Fauci, A. S. (2020). Coronavirus infections-more than just the common cold. Jama, 323(8), 707-708. http://dx.doi.org/10.1001/jama.20200757

Petraccia, L., Liberati, G., Masciullo, S. G., Grassi, M., \& Fraioli, A. (2006) Water, mineral waters and health. Clinical nutrition, 25(3), 377-385. https://doi.org/10.1016/j.clnu.2005.10.002

Popkin, B. M. (2003). The nutrition transition in the developing $\begin{array}{llr}\text { world. Development } & \text { policy review, } 21(5-6), & 581-597\end{array}$ https://doi.org/10.1093/jn/131.3.871S

Popkin, B. M., D'Anci, K. E., \& Rosenberg, I. H. (2010). Water, hydration, and health. Nutrition reviews, 68(8), 439-458. https://doi.org/10.1111/j.1753 4887.2010.00304.x

Prasad, A. S. (2000). Effects of zinc deficiency on Th1 and Th2 cytokine shifts. The Journal of infectious diseases, 182(Supplement_1), S62-S68. https://doi.org/10.1086/315916

Sabetta, J. R., DePetrillo, P., Cipriani, R. J., Smardin, J., Burns, L. A., \& Landry, M. L. (2010). Serum 25-hydroxyvitamin $d$ and the incidence of acute vira respiratory tract infections in healthy adults. PloS one, 5(6), e11088 https://doi.org/10.1371/journal.pone.0011088

Schmidt, L. E., \& Dalhoff, K. (2002). Food-drug interactions. Drugs, 62(10), 1481-1502. https://doi.org/10.2165/00003495-200262100-00005

Scrimshaw, N. S., \& SanGiovanni, J. P. (1997). Synergism of nutrition, infection, and immunity: an overview. The American journal of clinical nutrition, 66(2), 464S-477S. https://doi.org/10.1093/ajen/66.2.464S

Sherman, A., R., Spear, A., T., (1993) Iron and immunity. In Nutrition and Immunology, New York and London: Plenum Press. pp. 285-307 https://doi.org/10.1079/095442200108728981

Shi, Y., Wang, Y., Shao, C., Huang, J., Gan, J., Huang, X., ... \& Melino, G. (2020) COVID-19 infection: the perspectives on immune responses. Cell Death \& Differentiation, 27(5), 1451-1454. https://doi.org/10.1038/s41418-020-0530-3 Xu, Z., Shi, L., Wang, Y., Zhang, L., Huang, L., \& Zhang, C. (2020). Pathological finding of COVID-19 associated with acute respiratory distress syndrome. Lancet Respiratory Medicine. https://doi.org/10.1016/S2213-2600(20)30076-X 